\title{
Price Discovery on Stock Index Futures markets under Extreme Events: Evidence from China
}

\author{
Qian Zhang (PhD, Lecturer) \\ Shanghai University, SHU-UTS SILC Business School, China
}

Doi:10.19044/esj.2018.v14n25p190 URL:http://dx.doi.org/10.19044/esj.2018.v14n25p190

\begin{abstract}
In this paper, the price discovery function of stock index futures for spot stock index is studied in view of the soaring and plunging periods of Chinese stock market in recent years. We use the VECM model to do empirical research under periods of stationary, boom and slump. The results show that there is a long-term relationship between CSI 300 index and CSI 300 index futures. During the stable period of Chinese stock market, the CSI 300 stock index futures are sensitive to the short-term impact, and its ability of price discovery is obviously. However, during the period of boom and collapse, the price discovery function of CSI 300 index futures is weak.
\end{abstract}

Keywords: Stock index futures; linkage; price discovery

\section{Introduction:}

The linkage between the spot and futures market has been an area of extensive empirical research. The stock index futures markets, which are closely related to the spot market, has the characteristics of both stocks and futures. Related issues about the price linkage between the spot and futures markets, transmission of volatility, and so on, have a positive practical significance for the participants in the securities markets. From the perspective of traders, understanding the link between stock index futures and spot stocks can help them make better investment decisions and use effective hedge strategies against risks. Additionally, in a stable and mature financial market, the price discovery function of stock index futures and the stability of its linkage with the stock market will be helpful for the market managers to develop relevant policies, maintain the market order.

Chinese CSI 300 stock index futures were listed in 2010. Although it is eight years old, it is still in the stage of gradual improvement. The year of 2015 was a very special year for the stock market. From the end of 2014 to the first half of 2015, the stock index has been soaring all the way. Since the year of 2010 , it is the first time for the stock marketto have such kind of extreme 
volatility. The stock market crashhas a special meaning for studying the linkage effect between CSI 300 index futures and the stock market especially.Under the influence of such an extreme event, to study whether the price guidance relationship between China's spot goods and futures will change or notis the significance of this paper.

\section{Literature review}

Since the first introduction of stock index futures in the United States, its advantage of risk aversion with stock index futures has attracted more and more attention and is welcome for western countries. Scholars has done much empirical analysis for the stock index futures with a multi-angle, in which the linkage between spot and futures market occupies the most important position. Research on the linkage of the spot and futures market has focused on the volatility and the price guide of stock index futures for the spot market.

\section{Correlation between stock index futures volatility and spot volatility}

The impact of stock index futures on spot market volatility can be broadly divided into three cases, which are stable market, strengthening market volatility and not affecting market volatility. Bologna and Cavallo (2002) studied the impact of the introduction of stock index futures on the volatility of Italian stock index futures market. Under a GARCH model research, the stock index futures is listed decreased the volatility of the stock market in Italy, and the stock index futures is introduced to speed up the reaction speed of the stock market for information, and also improve the efficiency of the stock market. Ryoo and Smith (2004) studied the linkage of the KSPI200 index futures and the stock market in Korea with the historical data, and the empirical study finds that the stock index futures listed accelerates the reaction rate of the stock market for information, thereby increasing the stock market volatility. Floros and Vougas (2006) analyzed the FTSE/ASE - 20 and FTSE/ASE Mid 40 stock index futures and corresponding spot market, and concluded that the FTSE/ASE - 20 index futures has brought positive effect to Greece's stock spot market volatility, the stock market respond to the information more quickly. Under the influence of stock index futures, the FTSE/ASE Mid 40 index actually slowed down its reaction to the market, and the effect of historical information on prices was also weakened. Sahu (2008) using GARCH model to study CNY Nifty index between 1995 and 2007, and found that stock index futures will not affect the stock market, but the response speed of the stock market for information was improved, so as to improve the efficiency of the market at the same time,.

Tokat (2010) studied the risk transitivity of the stock market in Turkey with the GARCH model, and found that the risk spillover effect between the stock index futures market and the stock market is bi- directional, and the 
information asymmetry between the two markets is more serious. Debasish (2011) studied the Nifty index and CNX Bank index futures between 2000 to 2007, and did the qualitative analysis on the spot intraday volatility correlation, then draw the conclusion that the three stock index and its corresponding index futures volatility does exist significant correlation. Huang (2012) used the GARCH model and ICSS model to study the risk transfer between stock index futures markets and spot markets in the United States, Britain and Japan. Huang believes that there is an asymmetric transmission of volatility between stock index futures and spot markets in these three countries, and there is a two-way correlation between the risks of stock index futures in the UK and the US. Deville, Gresse and Severac (2014) studied the CAC 40 index futures with the 5 minutes high frequency data of VAR model, and found that the stock index futures and stock market volatility and liquidity are increased obviously, and also improve the efficiency of the spot market.

Liu junqi and Tian shuxi (2004) studied the risk linkage of stock index futures market and stock market in different countries, and draw the conclusion that the waterfall effect, which was resulted in the risk accumulation and diffusion of the stock index futures market, will lead to the intensity of the spot market volatility. Li hua and cheng jing (2006) studied the impact of the introduction of Japanese stock index futures on the volatility of the stock market in Japan. Empirical research was done in four different periods of the listed time for Nikkei 225 stock index futures in SIEMX, OSE and CME respectively. With the GARCH model, they found that at the beginning of the launch of stock index futures market, the stock index futures will certainly bring fluctuations to the stock market, but soon it will be calm. In the long term, the retreat of the Nikkei 225 stock index futures has had little impact on the spot market volatility. Liu and Yang (2007) did the qualitative analysis of how the lunch of stock index futures is to influence the stock spot market volatility of different markets, and draw the conclusion that the launch of stock index futures have not intense the volatility of the stock market, but made the stock market more stable instead. Xiong xiong, Wang fang and Zhang wei et al. (2009) used BEKK model and Granger causality test to study the influence of A50 futures on the volatility of CSI 300 index and Shanghai composite index. They did the empirical analysis with data from October 2006 to March 2008 days, and concluded that the CSI 300 index has volatility transmission effect on the A50 index futures. Additionally, the CSI 300 index has speeded up the stock market's reflect on the information of the market. However, there is no volatility spillover effect between A50 index futures and the Shanghai composite index. Xing and Zhang (2010) studied the volatility effect between the simulated CSI 300 index futures and the CSI 300 index with TARCH model, and results show that the initial introduction of the simulated CSI 300 index futures increased the volatility of the CSI 300 index, and the 
amplification effect gradually disappeared with time. In the long run, the asymmetry of the stock index has been amplified by the introduction of CSI 300 index futures. Xu and Wu (2012) studied the influence of CSI 300 stock index futures to the stock market in China with simultaneous equations model. They draw the conclusion that, in the first year of the launch of stock index futures, the spot market volatility was enhanced, and with the investors' trading moved from the spot market to the futures market, which leads to increasing of the information asymmetry degree in the stock market.

Zuo, Liu and Zeng (2012) used the nonparametric method to estimate overall volatility, continuity and volatility of the stock index futures and stock index, and found a two-way spillover effect of information transmission between the futures and spot market, and the volatility of stock market will influence the futures market discontinuously. But the futures market has no impact on subsequent spot market. Zhao and Huang (2014) studied the volatility between the stock index futures market and the stock market in China. With the co integration test, VAR model, VEC model method, the studied the linkage between the CSI 300 stock index futures in China and the Shanghai composite index. They found that and there is a long-term equilibrium relationship between stock spot market and the stock index futures market, and the stock index futures market has advocated helped the falling of the spot market volatility. Wang and Suo (2014) analyzed the risk correlation between the spot market are and stock index market with the spot highfrequency of a minute data from April 2010 to April 2012 in China under multiple fractal drop by drop crossing method. According to the empirical results, they found that there is a long-term cross correlation between the CSI 300 stock index futures and the stock market, which means when volatility increases in one market, in the other market's relative volatility will increase. Wang,Ge and Peng (2015) did empirical research by establishing the model GRACH and EGARCH models, and found that the risk of stock index futures market and spot market volatility are closely linked. Additionally, to a certain extent the launch of stock index futures eased the stock market volatility. Moreover, when market news tends to improve the long positions, the volatility in the stock index futures market is more intense.

\section{Price discovery in stock index futures markets}

Kawaller, Paul Koch and Harris (1987) argued that, the futures market is determined by the comprehensive information and market supply and demand, and the reflection of the stock market for market information is relatively slow, so the stock index futures will change before the stock market. At the same time, with the multiple regression and least square method, they found that the price change of S\&P500 stock index futures is significantly 20 to 45 minutes before the stock market. Stoll and Whaley (1990) studied the influence of S\&P 
500 - stock index futures and stock index futures MM to the stock market, and found that the price change of S\&P500 stock index futures is significantly 5 to 10 minutes before the stock market. At the same time, between there is a bidirectional leading relationship between the stock index futures market and stock market, to a certain extent the price of the lag of stock price index could predict the futures market price to some extent. Chu, Hsieh and Tse (1999) studied price discovery in the S\&P 500 - stock index futures market the co integration analysis, and found that the stock index futures market plays a major role of price discovery, and when prices fluctuate dramatically, the stock market will be adjusted to restore the equilibrium level mainly through the stock index futures markets. With Granger causality analysis, Lin, Chen and Hwang (2003) found the mutual Granger reason for the Taiwan stock index futures and stock markets prices, which is to say, a bi-directional leading relationship between the stock index futures of Taiwan and the stock market in Taiwan.

Lafuente (2007) studied the price discovery in Spanish stock index futures market. According to the result of VAR model, the listing of stock index futures did not obvious guide the stock market, and price discovery in the stock index futures is not in good performance. Chen and Gau (2009) studied price discovery ability in the Taiwan stock index, stock index futures market and stock index options market. With the VECM model, the authors found that with the decrease of the price change quantity of stock index futures price discovery ability also weakens. Pati and Rajib (2011) studied volatility spillover sexual contact of CNX Nifty index and the spot market by establishing BEKK GARCH model. The empirical analysis is concluded that, there is a two-way between both markets, and the price discovery of the stock index futures market to spot market is more obvious. Yang, Zhou and Yang (2012) studied the price discovery of the CSI 300 stock index of China by establishing the ECM-GARCH model. They found that, the CSI 300 stock index futures had a big impact on the spot market at the beginning, the price discovery of CSI 300 index futures did not play well. On the contrary, the spot market occupied the main position in the whole system of price discovery instead. Ullah and Shah (2013) studied the leading lag relationship between stock index futures and spot markets in Pakistan based on the efficient market hypothesis. With the historical trading data of KSE100 index from 1995 to 2012 , they establish a GARCH $(1,1)$ model and find that the price of the stock index futures on the spot market has guide effect indeed, but with the Granger causality test they found the price of a stock index futures will cause the stock index price change. Ersoy and Citak (2015) suggested that due to the irrational traders and market friction factors, the stock index futures market and the stock market will not immediately response to the market information, so the prices of both have lag relationship. 
Cheng and Liu (2003) studied the co integration relationship of Hong Kong's index futures and the spot market in Hong Kong, and found long-term and stable price linkage relationship between them. But they did not do further studies for the way of price guid. Xiao and Wu (2004) studied lag relationship between stock index futures and spot of standard \& poor's 500 index, and found that there is a real-time relationship between the stock index futures and the spot market of S\&P 500 index, and the reaction of the futures market for information is ahead of the spot market.Ren and Li (2006) did an empirical analysis on the linkage between stock index futures and spot markets with a minute high-frequency data of the S\&P 500 stock index through analysis the VAR model, and the price changes of stock index futures is ahead of the spot market, which means that the stock index futures market is more sensitive to information. Ge and Ye (2008) used the co integration test, Granger causality test and variance decomposition methods to find the relationship between futures and spot price of CSI 300, and found that there is no co integration relationship between specification and no long-term equilibrium relationship between them the futures and spot prices. The results of Granger causality test show that stock index has more obvious guidance for futures, and stock index futures have very weak guidance for spot prices. Hua and Liu (2010) used the method of Granger causality test and VEC model on the one minute high frequency data of CSI 300 index futures to study if there is price discovery on stock index futures, and found that the CSI 300 index futures lead spot price 7 minutes. Chen, Li and Liu (2013) analyzed the validity of CSI 300 stock index futures from the perspective of dynamic relationship, and they found that the stock index futures on the spot guidance function and price discovery function is not obvious, the stock index futures market in China still needs to improve efficiency.

With the recursive co-integration and public factor model, $\mathrm{Gu}$ and $\mathrm{Ye}$ (2013) analyzed the dynamic relationship between high frequency data of CSI 300 stock index futures and spot index. It was found that the price discovery in stock index futures markes did not play a role at the beginning of its operation. But two months after the CSI 300 stock index futures were listed, the prices discovery in stock index futures markes begin to take effect and gradually increase. Judge and Reancharoen (2014) summarized the studies on the guiding relationship between futures prices and futures prices. In developed financial regions led by the United States, stock index futures market has a complete function of price discovery. In emerging markets such as Thailand and Taiwan, spot goods play a leading role in guiding prices. Yang and Zhou (2012), Song (2016) used nonlinear models such as momentum consistent threshold autoregressive (momentum consistent threshold autoregressive) to study the price discovery, and found that there is a two-way causal relationship of mutual guidance in short-term current prices. But in the long run, there is 
only a long-term causal link between spot and futures. Yang dongxiao (2015) used PT model to analyze the high-frequency data of HS300 stock index futures, and found that stock index futures have a high price discovery contribution. Li (2016) studied the 5min high-frequency data of stock index futures (IF300, IHS0, IC500) and its spot markets, and found that the contribution of futures price discovery was significantly higher than that of spot markets. Yang (2014) found that when there was systemic risk in the market, the turning point of stock index futures market was about 1-3 minutes before the change of the spot market. With the ARCH series model, Tian (2016) find that the spot markets under the period of the positive feedback, there are market fluctuations accumulation and risk spillover linkage reaction between the stock index markets and spot markets. Yang and Yang (2017) selected the 5 minutes of high frequency data from June 15, 2015 to August 26 2017, used the E-G two-step co integration test, they stuied the crash during the CSI 300 stock index futures and CSI 300 index. The results show that the CSI 300 stock index futures still have the function of price discovery during the stock market crash, but there is a one-way volatility spillover to the spot market, which has a certain "help fall" effect.

\section{Methodology \\ Methods of price guidance}

We use two methods to find the price guidace of CSI 300 index futures to CSI 300 index. Firstly, we use the co-integration test to finde if there a cointegration relationship between CSI 300 index futures and CSI 300 index. Secondly, we use granger causuality test to find if the prices of CSI 300 index futures are the granger reason of the changing price of CSI 300.

\section{Co-integration test}

When there is some kind of stable linear combination between nonstationary variables, we can say that there is a co-integration relationship between these time series variables and there is a long-term equilibrium relationship. Suppose there are $\mathrm{n}$ time series, $\mathrm{y} 1 \mathrm{t}, \mathrm{y} 2 \mathrm{t}, \ldots \ldots, \mathrm{ynt}$. If each sequence is $\mathrm{d}$ order single integer and there is a non-zero vector $\mathrm{x}_{1}, \mathrm{x}_{2}, \ldots \mathrm{x}_{\mathrm{n}}$, so $\mathrm{XY}=$ $\mathrm{x}_{1} \mathrm{y}_{1 \mathrm{t}}+\mathrm{x}_{2} \mathrm{y}_{2 \mathrm{t}}+\ldots . .+\mathrm{x}_{\mathrm{n}} \mathrm{y}$ nis $(\mathrm{d}-\mathrm{b})$ order single integer sequence, $0<\mathrm{b}<\mathrm{d}$; then we say there is a co-integration relationship between $\mathrm{X}$ and $\mathrm{Y}$.

\section{Granger causality test}

Granger (1969) argued that for two different time series $\mathrm{X}$ and $\mathrm{Y}$, if the change in $\mathrm{X}$ caused the change in $\mathrm{Y}$, then the change in $\mathrm{X}$ should lead to the change in $\mathrm{Y}$. To verify that $\mathrm{X}$ is the cause of change in $\mathrm{Y}$, the following conditions need to be met two conditions: firstly, to verify whether the introduction of $\mathrm{X}$ sequence can help improve the prediction of $\mathrm{Y}$ sequence; 
secondly, the reverse prediction of $\mathrm{Y}$ sequence to $\mathrm{X}$ sequence cannot be improved. If these two conditions are not met, there is a third variable that causes changes in both the $\mathrm{X}$ and $\mathrm{Y}$ sequences. Assuming that $\mathrm{X}_{\mathrm{t}}$ and $\mathrm{Y}_{\mathrm{t}}$ are stable, the Granger causality test model can be expressed as:

$$
\begin{aligned}
& \mathrm{Xt}=\mathrm{C}_{1}+\sum_{\mathrm{j}=1}^{\mathrm{p}} \alpha_{\mathrm{j}} \mathrm{X}_{\mathrm{t}-\mathrm{j}}+\sum_{\mathrm{j}=1}^{\mathrm{q}} \beta_{\mathrm{j}} \mathrm{Y}_{\mathrm{t}-\mathrm{j}}+\mu_{1 \mathrm{t}} \\
& \mathrm{Yt}=\mathrm{C}_{2}+\sum_{\mathrm{j}=1}^{\mathrm{p}} \gamma_{\mathrm{j}} \mathrm{Y}_{\mathrm{t}-\mathrm{j}}+\sum_{\mathrm{j}=1}^{\mathrm{q}} \delta_{\mathrm{j}} \mathrm{X}_{\mathrm{t}-\mathrm{j}}+\mu_{2 \mathrm{t}}
\end{aligned}
$$

Where, $\mathrm{C}_{1}$ and $\mathrm{C}_{2}$ are constant terms, and $\mathrm{p}$ and $\mathrm{q}$ are optimal lag periods, and $\mu_{1 \mathrm{t}}$ and $\mu_{2 \mathrm{t}}$ are the white noise term. If $\beta_{\mathrm{j}}=0$, and $\delta_{\mathrm{j}}=0$, then the $\mathrm{X}$ and $\mathrm{Y}$ sequences are independent of each other. If $\beta_{j} \neq 0, \delta_{j}=0$, then the causality of the $\mathrm{Y}$ sequence is the Granger causality of the $\mathrm{X}$ sequence. If $\beta_{\mathrm{j}}=0, \delta_{\mathrm{j}} \neq 0$, then it can be concluded that $\mathrm{X}$ sequence is the Granger causality of $\mathrm{X}$ sequence, or there is a bidirectional Granger causality between $\mathrm{X}$ sequence and Y sequence.

\section{Methods of price discovery VECM Model}

The time series of variables is supposed to be non-station able and co integration, which is the precondition for establishing the error correction model. There is a co-integration relationship between variables, which shows that the variable exists a long-term equilibrium relationship. In order to maintain the long-term and stable relationship, error correction mechanism is used for short-term dynamic adjustment. VECM model is a VAR model with co-integration constraint. The following are the basic expressions of VECM:

$$
\begin{aligned}
& \ln \mathrm{Y}_{\mathrm{t}}=\mathrm{a}_{0}+\mathrm{a}_{1} \gamma_{\mathrm{t}-1}+\sum_{\mathrm{i}=1}^{\mathrm{p}} \mathrm{b}_{\mathrm{i} 1} \mathrm{X}_{\mathrm{t}-1}+\sum_{\mathrm{i}=1}^{\mathrm{p}} \mathrm{C}_{1 \mathrm{i}} \mathrm{Y}_{\mathrm{t}-\mathrm{i}}+\varepsilon_{1 \mathrm{t}} \\
& \ln \mathrm{X}_{\mathrm{t}}=\mathrm{a}_{0}+\mathrm{a}_{1} \gamma_{\mathrm{t}-1}+\sum_{\mathrm{i}=1}^{\mathrm{p}} \mathrm{b}_{\mathrm{i} 1} \mathrm{Y}_{\mathrm{t}-1}+\sum_{\mathrm{i}=1}^{\mathrm{p}} \mathrm{C}_{1 \mathrm{i}} \mathrm{X}_{\mathrm{t}-\mathrm{i}}+\varepsilon_{1 \mathrm{t}}
\end{aligned}
$$

In the formulas above, $\mathrm{X}_{\mathrm{t}}$ and $\mathrm{Y}_{\mathrm{t}}$ are the core variables, which will be the futures price of the CSI 300 index and the spot price of the index. However, the research object of this paper is China's stock index futures, so some Chinese macroeconomic variables are added as control variables.

In the VECM model, as an error correction term, a $\gamma_{\mathrm{t}-1}$ plays a very important role in the formal error correction. In the case of short-term price deviation, the error correction term reflects the price adjustment effect of stock index futures or stock spot index on the deviation. The coefficient of error correction term a reflects that stock index futures or stock index spot plays a positive or negative price correction role, and the absolute value of a1 reflects the correction strength. If the VECM the estimated results show that the effect of error correction of stock index spot is significant in stock index futures, then the current balance of the relationship between the spot is broken, mainly through spot prices do not reflect market information in time, and the futures market has reflected the information rapidly. The leading of spot prices to futures prices is also proved in a long-term. 
The lag term in the error correction model coefficient reflects the lag of futures and spot and in its size of the item or cross correlation, and the shortterm stock index futures and spot price between the leading effects. Based on VECM empirical results, in the spot price correction formula, the lag coefficient significantly before the futures price, which means that the stock index futures is ahead of the spot price and illustrates the price discovery of the futures price has function to the spot price. If the VECM results showed that the spot of the lag of error correction in the price is larger, then the price discovery of futures is very weak, but in the event of a short term deviation, spot prices have leading effect.

\section{Related Variables and Data descriptions}

As China is a socialist country, the development of China's stock market is different from those of western capitalist countries. Stock market follows the western freedom trend of the development of capitalism, and the development of China's stock market started in joint-stock reform of state-owned enterprises, so the development of financial market in China has a lot to do with our country's economic policy. According to the basic hypothesis, different financial markets in the same country are built on the same economic basis, and affected by the same macro variables. So even if the reaction mechanism of different markets to the information of the macro are distinct, their prices will still be affected by macro policy, so the linkage between stock index futures on the spot will be affected by macroeconomic factors. Therefore, some macroeconomic factors can be introduced as co variables when studying the short-term correction relationship between stock index futures and spot prices.

First of all, as studying the linkage between stock index futures and spot prices, we use the stock index futures and spot prices. In this paper, the stock index of CSI 300 and the historical closing price of its futures are selected. Since the general financial sequence is not stable, we first calculate the first order difference of the logarithmic rate of return of the daily transaction price of stock index futures.

Secondly, according to Cheng (2010), the stock price is closely related to monetary policy, and he has verified through empirical evidence that the fluctuation of interest rate will affect the fluctuation of stock market price. Therefore, we take the overnight borrowing rate between Banks in Shanghai as one of the co variables in the study of stock index futures spot price correction. Choose Shanghai interbank overnight interest rates, there are two main reasons: first, in view of the main variables chosen is degree of data, using the central bank set the one-year deposit rate is obviously not right, it is stable in a fixed period; second, as the CSI 300 stock index calculates 300 stocks listed on the Shanghai and Shenzhen stock exchanges, it is more 
appropriate to use the overnight borrowing rate between Shanghai and Shenzhen.

Third, Xiong, Wen etc. (2015) also studied the relationship between the $\mathrm{RMB}$ exchange rate and stock price, and found that the exchange rate for the stock market volatility has a guiding role. So in this paper, we use the exchange rate of RMB against US dollar as a covariate. The capital market of the United States has a long history of development and its authority in the global market is well known. Therefore, the exchange rate of RMB against the US dollar is representative to some extent.

Fourth, China's stock market and the stock index futures market started relatively late, the experience of the western capitalist will be used in the process of development. So the linkage effect in the futures, spot a short-term correction can join one of the international market share index as covariate. In this paper, we choose the NSDAQ index, which has become one of the world's key stock index, as one of the variables.

\section{Data description}

The data used in this article is downloaded from the WIND database. It is given in this paper, this paper is based on the extreme events of this particular time background, so we use the day's closing price of the CSI 300 stock index futures and spot prices, the NASDAQ index, overnight interest rates, the RMB against the dollar could be divided into three periods: the period from April 30, 2010 to November 18, 2014 as the stationary phase, the period from November 20, 2014 to June 11, 2015 is the period of inflation, the period from December 6, 2015 to June 29, 2016 is the period of sharp decline for data empirical analysis.

\section{Statistical description of stable period data}

The related statistics of stationary period of the CSI 300 index futures and spot price is shown in Table1. We find that the standard deviation, mean, median, etc of CSI 300 stock index futures and spot prices are very close to the indicators. JB statistics of futures, the spot price and yield sequences are more than 100, and the $\mathrm{P}$ value is almost zero. We conclude that the CSI 300 stock index futures, the spot price and earnings sequences are not subject to normal distribution. The peak value of the cash yield series of CSI 300 stock index futures is greater than 4, so the yield sequence shows the characteristics of peak value and tail value. 
Table 1 Statistics of stationary period

\begin{tabular}{lllll}
\hline & GZQH & ZSXH & RQH & RXH \\
\hline Mean & 2591.01 & 2594.39 & -0.00 & -0.00 \\
Median & 2522.11 & 2523.20 & -0.00 & -0.00 \\
Max. & 3548.57 & 3606.00 & 0.05 & 0.06 \\
Min. & 2086.97 & 2062.80 & -0.07 & -0.08 \\
S.D. & 342.77 & 348.29 & 0.01 & 0.01 \\
Skewness & 0.71 & 0.72 & -0.13 & -0.02 \\
Kurtosis & 2.56 & 2.65 & 4.97 & 6.02 \\
JB & 100.30 & 100.55 & 180.45 & 417.53 \\
P & 0.00 & 0.00 & 0.00 & 0.00 \\
\hline
\end{tabular}

\section{Statistical description of boom data}

The related statistics of boom period of the CSI 300 index futures and spot price is shown in Table 2. During the boom, the median of stock index price and futures price are high, and the maximum yield is over two hundred. Even though some yields present negative, the overall surge phenomenon is obviously. Since the stock index futures spot prices are in the soaring period, the standard deviation of the time series is high, indicating that the price volatility is relatively severe. Through the JB test, it can be concluded that the JB statistics of CSI 300 index futures is larger, and the P value is very small, that the yields of both present a rush took shape.

Table 2 Statistics of stationary period

\begin{tabular}{lllll}
\hline & GZQH & ZSXH & RQH & RXH \\
\hline Mean & 3916.35 & 3929.67 & 20.36 & 20.27 \\
Median & 3606.05 & 3623.90 & 23.31 & 14.80 \\
Max. & 5353.75 & 5335.40 & 235.35 & 352.00 \\
Min. & 2583.46 & 2566.00 & -347.43 & -346.80 \\
S.D. & 704.38 & 706.02 & 77.69 & 87.16 \\
Skewness & 0.39 & 0.42 & -1.10 & -0.45 \\
Kurtosis & 2.08 & 2.13 & 7.23 & 7.11 \\
JB & 8.29 & 8.39 & 128.91 & 100.51 \\
P & 0.02 & 0.02 & 0.00 & 0.00 \\
\hline
\end{tabular}

\section{Statistical description of collapse data}

The related statistics of collapse period of the CSI 300 index futures and spot price is shown in Table 3. We find that, the mean of the sequence of yield of the stock index futures and spot is around 15 or so, its minimum value is in between 300 and 500, which shows that this group of data is present a sharply falling trend in a slump in the mid-term. The standard deviation of the four groups of data is very high, indicating that stock index futures were affected by the overall environment during the collapse, and prices continued to fall and volatility was severe. Yields through the JB inspection, we can draw that the JB statistics of four groups is higher, and $\mathrm{P}$ value is very small, almost close to zero, shows that the time series present a rush thick tail shape. 
Table 3 Statistics of collapse data

\begin{tabular}{lllll}
\hline & GZQH & ZSXH & RQH & RXH \\
\hline Mean & 3688.47 & 3612.66 & -15.31 & -15.76 \\
Median & 3690.99 & 3638.30 & 0.66 & -3.20 \\
Max. & 5221.17 & 5199.80 & 281.45 & 367.20 \\
Min. & 2853.76 & 2749.60 & -370.32 & -513.20 \\
S.D. & 438.89 & 453.97 & 111.71 & 133.93 \\
Skewness & 0.98 & 0.98 & -0.66 & -0.32 \\
Kurtosis & 4.59 & 4.76 & 3.97 & 4.71 \\
JB & 40.92 & 44.92 & 17.37 & 21.56 \\
P & 0.00 & 0.00 & 0.00 & 0.00 \\
\hline
\end{tabular}

\section{Empirical test of price guidance}

In this section, the long-term relationship between CSI 300 stock index futures and spot stocks is verified through the stability test and co-integration test of data firstly. If there is a co-integration relationship between stock index period spot prices, it indicates that there is a long-term stable price relationship between the two markets. Then, we use Granger causality test to analyze the leading and lagging relationship of stock index futures or spot price changes.

\section{Full sample data \\ Co-integration test}

With the unit root test of all the variables, it can be concluded that the CSI 300 stock index futures and spot prices of logarithmic sequence is smooth conclusion. Then we do Johansen co integration test for the stock index futures price, spot price, the NASDAQ index and the spot exchange rate, results are listed in Table 4.

Table 4 Co-integration test of full sample

\begin{tabular}{|c|c|c|c|c|}
\hline $\begin{array}{l}\text { Number of Co- } \\
\text { integration }\end{array}$ & Eigen value & $\begin{array}{l}\text { Max-Eigen } \\
\text { Statisic }\end{array}$ & $\begin{array}{ll}0.05 & \text { Critical } \\
\text { Value } & \\
\end{array}$ & Prob. \\
\hline None & 0.23 & 33.57 & 28.59 & $0.02 * *$ \\
\hline At most one & 0.16 & 23.54 & 22.30 & $0.01 * *$ \\
\hline At most two & 0.06 & 17.45 & 15.90 & $0.05 *$ \\
\hline At most three & 0.02 & 4.21 & 9.16 & 0.67 \\
\hline
\end{tabular}

As shown in Table 5, the Max-Eigen Statistic is compared with the 5\% threshold. Since $4.21<9.16$, there are at most 3 sets of co-integration relationships among stock index futures price, spot price, NASDAQ index and spot exchange rate, which ensure that the VECM model could be used in the following part. Then, we do co integration test on the CSI 300 stock index futures and spot prices logarithmic sequence separately, to determine whether there is a long-term stable relationship between them. Results are shown in the Table 5. The Max-Eigen Statistic is compared with 5\% of the critical value, and there is a co-integration relationship between the CSI 300 index futures and spot logarithmic sequence. 
Table 5 Co-integration test of full sample

\begin{tabular}{|c|c|c|c|c|}
\hline $\begin{array}{l}\text { Number of Co- } \\
\text { integration }\end{array}$ & Eigenvalue & $\begin{array}{l}\text { Max-Eigen } \\
\text { Statisic }\end{array}$ & $\begin{array}{ll}0.05 & \text { Critical } \\
\text { Value } & \\
\end{array}$ & Prob. \\
\hline None & 0.18 & 24.13 & 15.89 & $0.00 * *$ \\
\hline At most one & 0.05 & 5.23 & 9.16 & 0.32 \\
\hline
\end{tabular}

\section{Granger causality test}

We have proved long-term stable equilibrium relationship between the CSI 300 stock index futures and spot price from the co integration test. Then the lead lag relationship between the CSI 300 stock index futures and spot price will be tested, we choose to achieve it through granger causality test. Since the granger causality test is very sensitive to lag order number, so we need to find the optimal lag order number, which are shown in the Table 6. According to the results of the test, the CSI 300 stock index futures returns is led to the Granger cause of the change of the CSI 300 stock index stock returns for any lag order unmber, while the stock index stock yield changes not reverse the Granger cause of the change of the yield of stock index futures. Therefore, the CSI 300 stock index futures have a one-way guiding effect on stock index spot. Table 6 Granger causality test of full sample

\begin{tabular}{llll}
\hline Lag & \multicolumn{1}{c}{ Assumption } & P & Conclusion \\
\hline \multirow{4}{*}{1} & Spot is not a granger reason for futures & 0.78 & Accepted \\
& Futures is not a granger reason for spot & 0.00 & Rejected \\
2 & Spot is not a granger reason for futures & 0.85 & Accepted \\
& Futures is not a granger reason for spot & 0.00 & Rejected \\
3 & Spot is not a granger reason for futures & 0.94 & Accepted \\
& Futures is not a granger reason for spot & 0.02 & Rejected \\
& Spot is not a granger reason for futures & 0.99 & Accepted \\
& Futures is not a granger reason for spot & 0.01 & Rejected \\
& Spot is not a granger reason for futures & 0.99 & Accepted \\
6 & Futures is not a granger reason for spot & 0.00 & Rejected \\
& Spot is not a granger reason for futures & 0.11 & Accepted \\
7 & Futures is not a granger reason for spot & 0.00 & Rejected \\
& Spot is not a granger reason for futures & 0.98 & Accepted \\
\hline
\end{tabular}

\section{Stable period data}

\section{Co-integration test}

With the unit root test of samples during stable period, it can be concluded that the CSI 300 stock index futures and spot prices of logarithmic sequence is smooth conclusion. Then we do Johansen co integration test for the stock index futures price, spot price, the NASDAQ index and the spot exchange rate, results are listed in Table 7. 
Table 7 Co-integration test of sample in stable period

\begin{tabular}{|c|c|c|c|c|c|}
\hline $\begin{array}{l}\text { Number of Co- } \\
\text { integration }\end{array}$ & Eigen value & $\begin{array}{l}\text { Max-Eigen } \\
\text { Statistics }\end{array}$ & $\begin{array}{l}0.05 \\
\text { Value }\end{array}$ & Critical & Prob. \\
\hline None & 0.10 & 112.21 & 28.59 & & $0.00 * *$ \\
\hline At most one & 0.02 & 17.75 & 22.30 & & $0.02 *$ \\
\hline At most two & 0.01 & 6.91 & 15.90 & & $0.04 *$ \\
\hline At most three & 0.01 & 5.81 & 9.16 & & 0.21 \\
\hline
\end{tabular}

As shown in Table 7, the Max-Eigen Statistic is compared with the 5\% threshold. Since112.21>28.59, there are at most 3 sets of co-integration relationships among stock index futures price, spot price, NASDAQ index and spot exchange rate, which ensure that the VECM model could be used in the following part. Then, we do co integration test on the CSI 300 stock index futures and spot prices logarithmic sequence separately, to determine whether there is a long-term stable relationship between them. Results are shown in the Table 8. The Max-Eigen Statistic is compared with 5\% of the critical value, and there is a co-integration relationship between the CSI 300 index futures and spot logarithmic sequence.

Table 8 Co-integration test of sample in stable period

\begin{tabular}{|c|c|c|c|c|c|}
\hline $\begin{array}{l}\text { Number of Co- } \\
\text { integration }\end{array}$ & Eigen value & $\begin{array}{l}\text { Max-Eigen } \\
\text { Statistics }\end{array}$ & $\begin{array}{l}0.05 \\
\text { Value }\end{array}$ & Critical & Prob. \\
\hline None & 0.09 & 106.59 & 15.89 & & $0.00 * *$ \\
\hline At most one & 0.003 & 4.03 & 9.16 & & 0.41 \\
\hline
\end{tabular}

\section{Granger causality test}

We have proved long-term stable equilibrium relationship between the CSI 300 stock index futures and spot price from the co integration test. Then the lead lag relationship between the CSI 300 stock index futures and spot price will be tested, we choose to achieve it through granger causality test. Since the granger causality test is very sensitive to lag order number, so we need to find the optimal lag order number, which are shown in the Table 9. According to the results of the test, the CSI 300 stock index futures returns is led to the Granger cause of the change of the CSI 300 stock index stock returns when the lag number is small. From the lag number of 5 , with the increasing of the lag number, the one-way guiding effect of the CSI 300 stock index futures on stock index spot disappears gradually.

Table 9 Granger causality test of sample in stable period

\begin{tabular}{llll}
\hline Lag & \multicolumn{1}{c}{ Assumption } & P & Conclusion \\
\hline \multirow{3}{*}{1} & Spot is not a granger reason for futures & 0.06 & Accepted \\
& Futures is not a granger reason for spot & 0.00 & Rejected \\
2 & Spot is not a granger reason for futures & 0.07 & Accepted \\
& Futures is not a granger reason for spot & 0.00 & Rejected \\
3 & Spot is not a granger reason for futures & 0.08 & Accepted \\
& Futures is not a granger reason for spot & 0.02 & Rejected \\
4 & Spot is not a granger reason for futures & 0.06 & Accepted \\
& Futures is not a granger reason for spot & 0.03 & Rejected
\end{tabular}




$\begin{array}{lll}\text { Spot is not a granger reason for futures } & 0.06 & \text { Accepted } \\ \text { Futures is not a granger reason for spot } & 0.10 & \text { Accepted } \\ \text { Spot is not a granger reason for futures } & 0.11 & \text { Accepted } \\ \text { Futures is not a granger reason for spot } & 0.16 & \text { Accepted } \\ \text { Spot is not a granger reason for futures } & 0.10 & \text { Accepted } \\ \text { Futures is not a granger reason for spot } & 0.28 & \text { Accepted }\end{array}$

\section{Boom period data \\ Co-integration test}

With the unit root test of samples during boom period, it can be concluded that the CSI 300 stock index futures and spot prices of logarithmic sequence is smooth conclusion. Then we do Johansen co integration test for the stock index futures price, spot price, the NASDAQ index and the spot exchange rate, results are listed in Table 10.

Table 10 Co-integration test of sample in boom period

\begin{tabular}{|c|c|c|c|c|c|}
\hline $\begin{array}{l}\text { Number of Co- } \\
\text { integration }\end{array}$ & Eigen value & $\begin{array}{l}\text { Max-Eigen } \\
\text { Statistics } \\
\end{array}$ & $\begin{array}{l}0.05 \\
\text { Value } \\
\end{array}$ & Critical & Prob. \\
\hline None & 0.21 & 31.34 & 28.59 & & $0.02 * *$ \\
\hline At most one & 0.18 & 26.14 & 22.30 & & $0.01 * *$ \\
\hline At most two & 0.07 & 16.65 & 15.90 & & $0.01 * *$ \\
\hline At most three & 0.02 & 3.27 & 9.16 & & 0.53 \\
\hline
\end{tabular}

As shown in Table 10, the Max-Eigen Statistic is compared with the 5\% threshold. Since $3.27<9.16$, there are at most 3 sets of co-integration relationships among stock index futures price, spot price, NASDAQ index and spot exchange rate, which ensure that the VECM model could be used in the following part. Then, we do co integration test on the CSI 300 stock index futures and spot prices logarithmic sequence separately, to determine whether there is a long-term stable relationship between them. Results are shown in the Table 11. The Max-Eigen Statistic is compared with 5\% of the critical value, and there is a co-integration relationship between the CSI 300 index futures and spot logarithmic sequence.

Table 11 Co-integration test of sample in boom period

\begin{tabular}{|c|c|c|c|c|c|}
\hline $\begin{array}{l}\text { Number of Co- } \\
\text { integration }\end{array}$ & Eigen value & $\begin{array}{l}\text { Max-Eigen } \\
\text { Statistics }\end{array}$ & $\begin{array}{l}0.05 \\
\text { Value } \\
\end{array}$ & Critical & Prob. \\
\hline None & 0.16 & 24.13 & 15.89 & & $0.00 * *$ \\
\hline At most one & 0.08 & 5.89 & 9.16 & & 0.32 \\
\hline
\end{tabular}

\section{Granger causality test}

We have proved long-term stable equilibrium relationship between the CSI 300 stock index futures and spot price from the co integration test. Then the lead lag relationship between the CSI 300 stock index futures and spot price will be tested, we choose to achieve it through granger causality test. Since the granger causality test is very sensitive to lag order number, so we need to find the optimal lag order number, which are shown in the Table 12. It can be seen 
from the test results in table 12 that the Granger causality between CSI 300 stock index futures and CSI 300 stock index spot prices is very insignificant during the boom period. In the case of a significant level of $10 \%$, the rate of return on stock index futures and spot between cannot as the Granger cause of the change of the other party, which means the short-term price lead - lag between relations is not obvious. Therefore, during the boom period, there may be other factors affecting the futures and spot yields of the CSI 300 index.

Table 12 Granger causality test of sample in boom period

\begin{tabular}{llll}
\hline Lag & \multicolumn{1}{c}{ Assumption } & P & Conclusion \\
\hline \multirow{2}{*}{1} & Spot is not a granger reason for futures & 0.32 & Accepted \\
& Futures is not a granger reason for spot & 0.27 & Accepted \\
2 & Spot is not a granger reason for futures & 0.57 & Accepted \\
& Futures is not a granger reason for spot & 0.69 & Accepted \\
3 & Spot is not a granger reason for futures & 0.68 & Accepted \\
& Futures is not a granger reason for spot & 0.80 & Accepted \\
& Spot is not a granger reason for futures & 0.88 & Accepted \\
5 & Futures is not a granger reason for spot & 0.91 & Accepted \\
5 & Spot is not a granger reason for futures & 0.96 & Accepted \\
6 & Futures is not a granger reason for spot & 0.84 & Accepted \\
& Spot is not a granger reason for futures & 0.97 & Accepted \\
7 & Futures is not a granger reason for spot & 0.84 & Accepted \\
& Spot is not a granger reason for futures & 0.99 & Accepted \\
\hline
\end{tabular}

\section{Slump period data \\ Co-integration test}

With the unit root test of samples during boom period, it can be concluded that the CSI 300 stock index futures and spot prices of logarithmic sequence is smooth conclusion. Then we do Johansen co integration test for the stock index futures price, spot price, the NASDAQ index and the spot exchange rate, results are listed in Table 13.

Table 13 Co-integration test of sample in slump period

\begin{tabular}{|c|c|c|c|c|c|}
\hline $\begin{array}{l}\text { Number of Co- } \\
\text { integration }\end{array}$ & Eigen value & $\begin{array}{l}\text { Max-Eigen } \\
\text { Statistics }\end{array}$ & $\begin{array}{l}0.05 \\
\text { Value }\end{array}$ & Critical & Prob. \\
\hline None & 0.22 & 38.52 & 28.59 & & $0.02 * *$ \\
\hline At most one & 0.15 & 24.31 & 22.30 & & $0.01 * *$ \\
\hline At most two & 0.07 & 16.01 & 15.90 & & $0.02 * *$ \\
\hline At most three & 0.02 & 2.57 & 9.16 & & 0.53 \\
\hline
\end{tabular}

As shown in Table 13, the Max-Eigen Statistic is compared with the 5\% threshold. Since $2.57<9.16$, there are at most 3 sets of co-integration relationships among stock index futures price, spot price, NASDAQ index and spot exchange rate, which ensure that the VECM model could be used in the following part. Then, we do co integration test on the CSI 300 stock index futures and spot prices logarithmic sequence separately, to determine whether there is a long-term stable relationship between them. Results are shown in the 
Table 14. The Max-Eigen Statistic is compared with 5\% of the critical value, and there is a co-integration relationship between the CSI 300 index futures and spot logarithmic sequence.

Table 14 Co-integration test of sample in slump period

\begin{tabular}{|c|c|c|c|c|c|}
\hline $\begin{array}{l}\text { Number of Co- } \\
\text { integration }\end{array}$ & Eigen value & $\begin{array}{l}\text { Max-Eigen } \\
\text { Statistics }\end{array}$ & $\begin{array}{l}0.05 \\
\text { Value }\end{array}$ & Critical & Prob. \\
\hline None & 0.16 & 21.77 & 15.89 & & $0.01 * *$ \\
\hline At most one & 0.08 & 4.18 & 9.16 & & 0.39 \\
\hline
\end{tabular}

\section{Granger causality test}

We have proved long-term stable equilibrium relationship between the CSI 300 stock index futures and spot price from the co integration test. Then the lead lag relationship between the CSI 300 stock index futures and spot price will be tested, we choose to achieve it through granger causality test. Since the granger causality test is very sensitive to lag order number, so we need to find the optimal lag order number, which are shown in the Table 15. During the crash, under 5\% significance level, the CSI 300 index futures yield change basic ahead of CSI 300 stock index stock returns, the futures price changes is the Granger cause of the change of the spot price. At the time of lag period 2 and lag period 3, not only is futures yield the Granger cause of spot rate of return, but spot rate of return is also the Granger cause of future rate of return, which have mutual influence. But on the whole, stock index futures still have a one-way guiding effect on spot during the crash.

Table 15 Granger causality test of sample in slump period

\begin{tabular}{llll}
\hline Lag & \multicolumn{1}{c}{ Assumption } & P & Conclusion \\
\hline \multirow{3}{*}{1} & Spot is not a granger reason for futures & 0.57 & Accepted \\
2 & Futures is not a granger reason for spot & 0.03 & Rejected \\
& Spot is not a granger reason for futures & 0.02 & Rejected \\
3 & Futures is not a granger reason for spot & 0.00 & Rejected \\
& Spot is not a granger reason for futures & 0.07 & Rejected \\
4 & Futures is not a granger reason for spot & 0.03 & Rejected \\
& Spot is not a granger reason for futures & 0.07 & Accepted \\
5 & Futures is not a granger reason for spot & 0.01 & Rejected \\
& Spot is not a granger reason for futures & 0.14 & Accepted \\
6 & Futures is not a granger reason for spot & 0.03 & Rejected \\
& Spot is not a granger reason for futures & 0.16 & Accepted \\
7 & Futures is not a granger reason for spot & 0.04 & Rejected \\
& Spot is not a granger reason for futures & 0.15 & Accepted \\
\hline
\end{tabular}

\section{Comparative analysis}

Based on the data of full sample, stable period, boom period and slump period, we use co-integration test and granger causality test, to test the longterm relationships between the CSI 300 stock index futures and spot prices. The results of co-integration test indicate that there is always a long-term stable relationship between stock index futures and spot prices. The results of 
Granger causality analysis also show the price guidance relationship between stock index futures and spot stocks.

After Granger causality test results for the data of the full sample and sample in stable period are very similar. That is, the stock index futures price has a one-way price guidance effect on spot price. But the difference is that the price guide of stock index futures on spot prices during stable period lasts for a relatively long time, and the CSI 300 index guiding effect for the spot gradually disappear from the lag of five, which may resulted by a large number of irrational trading during the boom and crash period.

During the period of boom, there is no Granger causality between stock index futures and spot stocks. This shows that, although there is a connection for the CSI 300 index futures price and spot price index during the boom, but there is no obvious lag leading relationship, there may be other macroscopic or microcosmic factors lead to the change of stock index futures and spot prices. Another possible reason is that, during the boom, traders are very sensitive to market information, so the stock index futures market and spot market of information in a timely manner to reflect, thus there is no lead lag relationship.

During the period of slump, the futures of the CSI 300 and the spot market showed the one-way guidance of futures to spot in most late stages. But when lag number is small, the stock index futures and spot prices will not be the mutual Granger reason occasionally. The reason may be that, due to the slump, traders will trade irrationally during the crash. In general, stock index futures are ahead of spot prices during the slump, leading to changes in spot prices.

\section{Empirical analysis of price discovery Full sample data}

With the previous co-integration test, we confirm that there is a long-term stable co-integration relationship between the CSI 300 index period and the spot price during the stable period. In this paper, VECM model is used to analyze the short-term linkage between core variables. Since VECM model is a deformation of VAR model, the optimal lag order should be determined first. The optimal lag order test results are shown in the following table.

Table 16 Optimal lag order of full sample

\begin{tabular}{lllllll}
\hline Lag & Long L & LR & FRE & AIC & SC & HQ \\
\hline 0 & 5536.37 & NA & 0.00 & -9.69 & -29.66 & -9.07 \\
1 & 786.11 & 4586.00 & 0.00 & -13.58 & -15.94 & -12.87 \\
2 & 7926.54 & $13.77^{*}$ & 0.00 & $-14.06^{*}$ & $-13.99 *$ & $-14.04^{*}$ \\
3 & 7634.53 & 24.59 & 0.00 & -14.05 & -22.99 & -14.04 \\
\hline
\end{tabular}

According to the principle of minimum statistic, the optimal lag order is 2. With the study of the OLS estimates of each variable, the VECM model is 
established to estimate, the results show that: Firstly, the correction coefficient of stock index spot VECM model are significant under the confidence level of $1 \%$, which means the CSI 300 stock index react fast enough for market information, and the reaction failure caused the relationship between the stock index futures spot price deviation, so in the short term correction, mainly by stock index spot price adjustments. However, stock index futures prices have been able to respond effectively to market information, so it is no longer necessary to make error adjustment in the short-term correction model. Therefore, it can be seen that the price discovery function of stock index futures is realized. Secondly, the coefficient of the error correction term of stock index spot reflects the adjustment intensity and direction of the variable to the phenomenon of price deviation. The coefficient of 0.01 indicates that the stock index spot will undergo a positive adjustment of 0.01 when a short-term deviation occurs. Thirdly, in the stock index spot VECM model, the lag of first order second order of the futures of coefficient were 0.32 and 0.11 , and are more significant at the same time, that one or two days in advance of the stock index futures price changes have a positive impact on changes in the spot price of the current period and the ability to predict, stock index futures price discovery.

Table 17 Results of VECM model of full sample

\begin{tabular}{llrll}
\hline & \multicolumn{2}{c}{$\Delta \mathrm{LQH}$} & \multicolumn{2}{c}{$\Delta \mathrm{LXH}$} \\
\hline & \multicolumn{1}{c}{ Coefficient } & $\mathrm{T}$ & coefficient & $\mathrm{T}$ \\
\hline $\mathrm{VECM}_{\mathrm{t}-1}$ & -0.00 & {$[-0.30]$} & $0.01^{* *}$ & {$[-5.48]$} \\
$\Delta \mathrm{LQH}_{\mathrm{t}-1}$ & -0.01 & {$[-0.78]$} & $0.85^{* *}$ & {$[17.55]$} \\
$\Delta \mathrm{LQH}_{\mathrm{t}-2}$ & -0.01 & {$[-0.83]$} & $0.41^{* *}$ & {$[-4.08]$} \\
$\Delta \mathrm{LXH}_{\mathrm{t}-1}$ & -0.02 & {$[0.21]$} & $0.32^{* *}$ & {$[-31.08]$} \\
$\Delta \mathrm{LXH}_{\mathrm{t}-2}$ & -0.01 & {$[0.38]$} & $0.11^{* *}$ & {$[-10.5]$} \\
$\mathrm{LIC}$ & -0.00 & {$[0.19]$} & 0.01 & {$[1.08]$} \\
$\mathrm{SR}$ & 0.00 & {$[0.09]$} & 0.00 & {$[0.22]$} \\
$\mathrm{C}$ & -0.06 & {$[-1.21]$} & -0.06 & {$[-1.26]$} \\
\hline
\end{tabular}

\section{Stable period data}

With the previous co-integration test, we confirm that there is a long-term stable co-integration relationship between the CSI 300 index period and the spot price during the stable period. In this paper, VECM model is used to analyze the short-term linkage between core variables. Since VECM model is a deformation of VAR model, the optimal lag order should be determined first. The optimal lag order test results are shown in the following table.

Table 18 Optimal lag order in stable period

\begin{tabular}{lllllll}
\hline Lag & LongL & LR & FRE & AIC & SC & HQ \\
\hline 0 & 5326.37 & NA & 0.00 & -9.69 & -9.67 & -9.69 \\
1 & 7680.11 & 4686.01 & 0.00 & -13.98 & -13.94 & -13.97 \\
2 & 7726.56 & 92.3 & 0.00 & -14.06 & $-13.99^{*}$ & -14.04 \\
3 & 7734.52 & $15.79 *$ & 0.00 & $-14.07^{*}$ & -13.99 & $-14.04^{*}$ \\
\hline
\end{tabular}


According to the principle of minimum statistic, the optimal lag order is 3. With the study of the OLS estimates of each variable, the VECM model is established to estimate, the results show that: Firstly, most coefficient for spot index are significant under the confidence level of $5 \%$, but the parameter estimation of stock index futures is generally not significant. This means that, at the time of the short-term deviation, prices are mainly implemented by adjusting the spot price. Since the futures prices had made a fairly rapid reflect to the market information, so it doesn't need more regulation, which indicates the well price discovery of stock index futures. Secondly, in the error correction model, VECMt-1 reflects short term deviation adjusting fixed role, VECM $_{\mathrm{t}-1}$ coefficient reflects the speed adjustment ability of the stock index spot and futures markets in the face of short-term shock, and the absolute value of coefficient reflects the adjustment speed, the greater absolute value means faster adjusting speed. Stock index futures of error correction coefficient is 0.02 , the stock index stock error correction coefficient is 0.2 , which means that the adjustment of the stock index stock faster than stock index futures. Thirdly, the stock index spot itself have an impact on the current price, the lag issue of stock index spot coefficient is 0.13 , two, three phases of lag of stock index spot coefficient is 0.1 , the information lag items for the current spot price has a positive regulatory role. Fourthly, macro variables such as NASDAQ index and spot exchange rate have little effect on the adjustment of stock index futures and spot prices, both of which are less than 0.001 .

Table 19 Results of VECM model of stable period

\begin{tabular}{lllll}
\hline & \multicolumn{2}{c}{$\Delta \mathrm{LQH}$} & \multicolumn{3}{c}{$\Delta \mathrm{LXH}$} \\
\hline \multicolumn{1}{c}{ Coefficient } & \multicolumn{1}{c}{$\mathrm{T}$} & \multicolumn{1}{c}{$\mathrm{T}$} \\
\hline $\mathrm{VECM}_{\mathrm{t}-1}$ & -0.02 & {$[-0.30]$} & $0.20^{* *}$ & {$[2.12]$} \\
$\Delta \mathrm{LQH}_{\mathrm{t}-1}$ & 0.22 & {$[-1.05]$} & $-0.13^{*}$ & {$[-1.85]$} \\
$\Delta \mathrm{LQH}_{\mathrm{t}-2}$ & 0.25 & {$[-0.83]$} & $-0.09^{* *}$ & {$[-2.08]$} \\
$\Delta \mathrm{LQH}_{\mathrm{t}-3}$ & 0.13 & {$[-1.05]$} & $-0.04^{*}$ & {$[-1.22]$} \\
$\Delta \mathrm{LXH}_{\mathrm{t}-1}$ & -0.23 & {$[0.83]$} & $0.13^{*}$ & {$[-1.97]$} \\
$\Delta \mathrm{LXH}_{\mathrm{t}-2}$ & -0.23 & {$[-0.38]$} & $0.10^{*}$ & {$[1.99]$} \\
$\Delta \mathrm{LXH}$ & -0.16 & {$[0.96]$} & $0.10^{*}$ & {$[2.55]$} \\
$\mathrm{LIC}$ & -0.0004 & {$[1.19]$} & 0.0005 & {$[1.28]$} \\
$\mathrm{SR}$ & 0.0005 & {$[0.99]$} & 0.0001 & {$[1.22]$} \\
$\mathrm{C}$ & -0.06 & {$[-1.21]$} & -0.06 & {$[-1.26]$} \\
\hline
\end{tabular}

\section{Boom period data}

With the previous co-integration test, we confirm that there is a long-term stable co-integration relationship between the CSI 300 index period and the spot price during the stable period. In this paper, VECM model is used to analyze the short-term linkage between core variables. Since VECM model is a deformation of VAR model, the optimal lag order should be determined first. The optimal lag order test results are shown in the following table. 
Table 20 Optimal lag order in boom period

\begin{tabular}{lllllll}
\hline lag & LongL & LR & FRE & AIC & SC & HQ \\
\hline 0 & 506.26 & NA & 0.00 & -7.53 & -7.48 & -7.51 \\
1 & 823.01 & $619.31^{*}$ & 0.00 & $-12.19^{*}$ & $-12.06^{*}$ & $-12.14^{*}$ \\
2 & 825.48 & 4.736 & 0.00 & -12.17 & -11.96 & -12.08 \\
3 & 827.53 & 3.89 & 0.00 & -12.14 & -11.84 & -12.02 \\
\hline
\end{tabular}

According to AIC criterion, it is concluded that the optimal lag period of VECM model in the slump period is 1 . Then, the estimation results of VECM model show that: Firstly, the only stock index spot error adjustment coefficient is significant, the other most significant lag coefficient, in boom times, which means the spot market will be valid for the current short-term deviation adjustment. The lag of coefficient is not significant, which means the price discovery of stock index futures is not well. Secondly, in the VECM model of stock index futures and spot stocks, spot exchange rate has a positive effect on the short-term deviation of futures and spot stocks. During the boom period, the link between stock index futures and spot stocks will also be affected by other macro factors.

Table 21 Results of VECM model of boom period

\begin{tabular}{lllll}
\hline & \multicolumn{1}{c}{$\Delta \mathrm{LQH}$} & \multicolumn{3}{c}{$\Delta \mathrm{LQH}$} \\
\hline & \multicolumn{1}{c}{ Coefficient } & \multicolumn{1}{c}{$\mathrm{T}$} & \multicolumn{1}{c}{ coefficient } & \multicolumn{1}{c}{$\mathrm{T}$} \\
\hline VECMt-1 & -0.12 & {$[0.49]$} & $0.55^{* *}$ & {$[2.08]$} \\
$\Delta$ LQHt-1 & 0.28 & {$[-1.07]$} & 0.19 & {$[-0.66]$} \\
$\Delta$ LXHt-1 & -0.25 & {$[1.03]$} & -0.12 & {$[0.41]$} \\
LIC & -0.08 & {$[0.71]$} & -0.12 & {$[1.39]$} \\
SR & $0.11^{* *}$ & {$[-2.56]$} & $0.15^{* *}$ & {$[-2.90]$} \\
C & 0.56 & {$[0.96]$} & 0.38 & {$[0.59]$} \\
\hline
\end{tabular}

\section{Slump period data}

With the previous co-integration test, we confirm that there is a long-term stable co-integration relationship between the CSI 300 index period and the spot price during the stable period. In this paper, VECM model is used to analyze the short-term linkage between core variables. Since VECM model is a deformation of VAR model, the optimal lag order should be determined first. The optimal lag order test results are shown in the following table.

Table 22 Optimal lag order in slump period

\begin{tabular}{lllllll}
\hline Lag & LogL & LR & FPE & AIC & SC & HQ \\
\hline 0 & 596.44 & NA & 0.00 & -7.67 & -7.55 & -7.62 \\
1 & 760.21 & $316.90^{*}$ & $0.00^{*}$ & $-9.74^{*}$ & $-9.55^{*}$ & $-9.66^{*}$ \\
2 & 764.27 & 7.75 & 0.00 & -9.74 & -9.47 & -9.63 \\
3 & 766.62 & 4.42 & 0.00 & -9.72 & -9.37 & -9.58 \\
\hline
\end{tabular}

According to AIC criterion, the optimal lag order of VECM model in the period of collapse is determined to be 1 order. Then, VECM model is established to estimate, the results are as follows: Firstly, the stock index 
futures and spot error adjustment and their respective lag before first order item coefficient is significant under the confidence level of $1 \%$, which means that during the slump, once the stability of the relationship between stock index futures and spot prices been broken, the stock index futures and spot prices both adjust accordingly. Secondly, the coefficient of error correction term of stock index futures is -0.30 , indicating that stock index futures will exert a strength of -0.30 to pull it back into the long-term stable relationship when short-term deviation occurs. The error correction coefficient of stock index spot is 0.63 , indicating that when there is a short term deviation, the stock index will produce a positive pull effect of 0.63 to restore the price relationship of the two prices to a long-term stable state. Thirdly, the lagging first-order term of stock index futures and spot stocks will also influence the spot price of stock index futures in the current period. In the VECM model of stock index futures, the delayed first-order stock index spot will have a positive impact of 0.48 , while the delayed first-order stock spot will have a positive impact of 0.50 . In the VECM model of stock index spot, the backward first-order stock index spot will have a negative adjustment effect of 0.57 , while the backward first-order stock spot will have a negative adjustment effect of 0.52 .

Table 23 Results of VECM model of boom period

\begin{tabular}{lllll}
\hline & \multicolumn{1}{c}{$\Delta \mathrm{LH}$} & \multicolumn{3}{c}{$\Delta \mathrm{LXH}$} \\
\hline & \multicolumn{1}{c}{ Coefficient } & \multicolumn{1}{c}{$\mathrm{T}$} & coefficient & $\mathrm{T}$ \\
\hline VECMt-1 & $-0.30^{* *}$ & {$[3.46]$} & $0.63^{* *}$ & {$[5.86]$} \\
$\Delta$ LQHt-1 & $0.48^{* *}$ & {$[-3.08]$} & $-0.57^{* *}$ & {$[3.26]$} \\
$\Delta$ LXHt-1 & $0.50^{* *}$ & {$[3.88]$} & $-0.52^{* *}$ & {$[3.61]$} \\
LIC & $-0.22^{* *}$ & {$[2.91]$} & $-0.38^{* *}$ & {$[4.01]$} \\
SR & -0.01 & {$[0.95]$} & -0.02 & {$[1.22]$} \\
C & $-1.99^{*}$ & {$[-2.71]$} & $-3.26^{*}$ & {$[-3.72]$} \\
\hline
\end{tabular}

\section{Comparative analysis}

Firstly, in the case of short-term deviation, the effect of VECM model on the price adjustment of stock index futures and spot prices is reflected in the price discovery in stock index futures markets. Estimation results of VECM model for the full and stable sample is similar. According to the coefficient of cross terms, futures prices lead one day before the spot prices, and price discovery obviously exists in the stock index futures.

The price discovery function of stock index futures is different during the period of boom and crash. During the boom, although the short-term deviation is adjusted mainly through the spot prices, the lag coefficient is not significant, which means that and both of the futures and spot prices don't have the price discovery function. Additionally, the adjustment of macro factors for the deviation is more obvious during boom period, which suggests that during the boom period the stock index spot prices might have been affected more from the macroscopic aspect. During the crash, stock index futures and spot prices 
both adjust for price deviation, and according to its lag coefficient of cross terms, the stock index futures and spot prices both have price discovery function. In order to compare and analyze the price contribution of different periods, impulse response is made for three periods respectively. The main results are shown in the following table.

Table 24 Comparison of price contribution in each period

\begin{tabular}{llllll}
\hline & Futures & \multicolumn{5}{l}{ Spot } \\
\hline $\begin{array}{l}\text { Contribution } \\
\text { spot prices }\end{array}$ & of & $\begin{array}{l}\text { Contribution } \\
\text { futures prices }\end{array}$ & $\begin{array}{l}\text { of } \\
\text { spot prices }\end{array}$ & $\begin{array}{l}\text { Contribution } \\
\text { futuribution prices }\end{array}$ \\
\hline Stable & $6.62 \%$ & $93.38 \%$ & $0.01 \%$ & $99.99 \%$ \\
Boom & $64.42 \%$ & $35.58 \%$ & $48.02 \%$ & $51.98 \%$ \\
Slump & $47.44 \%$ & $52.56 \%$ & $54.47 \%$ & $45.53 \%$ \\
\hline
\end{tabular}

By comparing the futures and spot prices contribution in different periods, price discovery of stock index futures and spot prices has been proved again. During the stable period, price discovery in the stock index futures is obviously. However, during the period of boom and slump periods, it is difficult to clearly identify the dominant difference between the prices of CSI 300 stock index futures and spot prices.

\section{Conclusion}

In this paper, the linkage of the CSI 300 index futures and spot prices is studied under stable, boom and slump periods. First of all, the stationary test and co integration test results show that the logarithmic sequence of the CSI 300 stock index futures and spot prices are stable and have co integration relationship, which explains a long-term equilibrium relationship between stock index futures and spot prices in the three periods. Next, we use Granger causality test to analyze the guiding relationship between stock index futures and spot prices, and we find that in a smooth and slump, there is a one-way leading relationship of the CSI 300 stock index futures price to the spot price, but in the stable effects of this guide does not last for a long time. But in slump period, the guide effect last long time. During the boom, there was no clear lag relationship between the CSI 300 index futures and spot prices. In combination with VECM model and impact response function, we studied the price discovery in the CSI 300 stock index futures market under short-term deviation impact in these three periods. During the stable period, the CSI 300 stock index futures respond to the short-term impact quickly and the price discovery ability of futures is reflected. However, during the period of boom and slump, the spot stock of CSI 300 index adjusts the short-term fluctuation quickly, and the price discovery ability of futures is not well reflected.

According to the empirical results of the boom period, it can be found that investors tend to make irrational trading decisions in the face of the continuous rise of the overall market. Investment traders tend to be highly sensitive to 
national macro information, which can lead to better price adjustment ability of stock index futures. Therefore, for management, standardization of information disclosure will eliminate the uncertainty factors of stock market. Traders should also be carefully trading, without blindly following others' trading behaviors during the boom, so as to prevent the aggravating effect of "herd effect" during the slump and boom. During the crash, the linkage between the stock index futures and spot is no longer unilateral, but in twoway, means that in the face of the market continued to fall, traders showed some doubt and uncertainty, and he reflection speed of stock index futures markets to market information tend to decline. At this time, traders need to consider more comprehensive and take the link between futures and spot as a dimension when making trading decisions. The influence of macro factors on stock markets is weak during the slump, which means that managers need more measures to stabilize the market.

Although China's stock index futures have become the more and more traded, the market still needs to be improved continuously. Especially after a slump period, although China securities regulatory commission issued the "fusing system" to prevent the information asymmetry caused by panic further drop sharply, the two meltdowns in 2016 did not bring the expected effect. On the contrary, they encouraged some traders to trade ahead of time, which contributed to the decline. The China securities regulatory commission stopped the mechanism on January 8, 2016. Although the fusing system failed this time, it is still a good attempt. China's futures market also needs to do further improvement of the regulatory system and risk management system, so as to control the further market risks better.

\section{Acknowledgement:}

Project supported by the National Social Science Foundation of China (Grant No. 17CJY062).

\section{References:}

1. Kawaller I, Koch P, Koch T. (1987). The temporal relationship between S\&P 500 futures and the S\&P 500 index. Journal of Finance, 42(5), 1309-1329.

2. Stoll H.R, Whaley R. E. (1990).The Dynamics of Stock Index and Stock Index Futures Returns. Journal of Financial and Quantitative Analysis, 25(4),441-468.

3. Chu Q. C, Hsieh W. G \&Tse Y. (1999). Price Discovery on the S\&P500 Index Markets: An Analysis of Spot Index, Index Futures, and SPDRs. International Review of Financial Analysis, 8, 21-34. 
4. Lin C., Hwang D. \& Chen S. 2003. An Application of Threshold Contrgration to Taiwan Stock Index Futures and Spot Markets. Review of Pacific Basic Financial Markets and Policies, 6(3),291-304.

5. Lafuente M. (2007). Introducing the Mini-Futures Contract on Ibex35: Implications for Price Discovery and Volatility Transmission. Spanish Economic Review, 10,197-219.

6. Pati P. \&Rajib P. (2011). Intraday Return Dynamics and Volatility Spillovers between NSE S\&P CNX Nifty Stock Index and Stock Index Futures. Applied Economics Letters, 18, 567-574.

7. Yang J., Yang Z. \& Zhou Y. 2012. Intraday Price Discovery and Volatility Transmission in Stock Index and Stock Index Futures Markets: Evidence from China. The Journal of Future Markets, 32(2),99-121.

8. Ullah H. \& Shah A., Lead-lag Relationship in Spot and Future Market: Evidence from Pakistani Stock Market KSE-100 Index. Business Review, 2013, 8(1), 135-148.

9. Bologna P. \&Cavallos L. (2002) Does The Introduction of Stock Index Futures Effectively Reduce Stock Market Volatility? Is the "Future Effect" Immediate? : Evidence from The Italian Stock Exchange Using GARCH. Applied Financial Economics, 12, 183-192.

10. Ryoo H. \& Smith G. (2004). The Impact of Stock Index Future on the Korean Stock Market. Applied Financial Economics, 14, 243-251.

11. Floros C. \&Vougas D. V. (2006). Index Futures Trading, Information and Stock Market Volatility:The Case of Greece. Derivatives Use, Trading \& Regulation Volume Twelve, 2,146-166.

12. Sahu D. (2006). Influence Spot Market Volatility? Evidence from Indian Stock Market. International Journal of Business Insight \& Transformation, 2, 99-104.

13. Tokat E. \&Tokat H. A. (2010). Shock and Volatility Transmission in the Futures and Spot Market, Evidence from Turkish Markets. Emerging Markets Finance \& Trade, 7, 92-104.

14. Debasish S. S. (2011). Spot and Futures, Market Relative Volatility. SCMS Journal of Indian Management, 7,94-105.

15. Huang P. (2012). Volatility Transmission across Stock Index Futures When There Are Structural Changes in Return Variance. Applied Financial Economics, 22,1603-1613.

16. Deville L., Gresse C. \&Severac B. (2014). Direct and Indirect Effects of Index ETFs on Sot-Future Pricing and Liquidity, Evidence from the CAC40 Index. European Financial Management, 20(2), 352-373.

17. Chen Y. \&Gau Y. (2009). Tick Size and Relative Rates of Price Discovery in Stock, Futures, and Options Markets, Evidence from The Taiwan Stock Exchange. Journal of Future Markets, 29(1), 74-92. 
18. Ersoy E. \&Citak L. (2015). Intraday Lead-lag Relationship between Stock Index and Stock Index Futures Markets, Evidence from Turkey. Business and Economics Research Journal, 6(3), 1-18.

19. Judge A, Reancharoen T. (2014). An empirical examination of the lead-lag relationship between spot and futures market : evidence from Thailand. Pacifica-Basin Finance Journal, 29, 335-358.

20. Yang J,Yang z,Zhou Y. (2012). Intraday price discovery and volatility transmission in stock index and stock index futures markets : evidence from China. Journal of futures Markets, 32(2), 99-121. 